\title{
Increased Incidence of Thyroid Disease in Patients with Celiac Disease: A Systematic Review and Meta-Analysis
}

\author{
Xin Sun ${ }^{1,2 *}$, Li Lu ${ }^{1,2}$, Rong Yang ${ }^{1,2}$, Yanbin $\mathrm{Li}^{1,2}$, Ling Shan ${ }^{1,2}$, Yang Wang ${ }^{1,2}$ \\ 1 Department of Endocrinology and Metabolism, The People's Hospital of China Medical University, \\ Shenyang, P.R. China, 2 Department of Endocrinology and Metabolism, The People's Hospital of China \\ Medical University, The People's Hospital of Liaoning Province, No.33 Wenyi Road, Shenhe District, \\ Shenyang 110013, Liaoning Province, P R China \\ *sunxin77@126.com
}

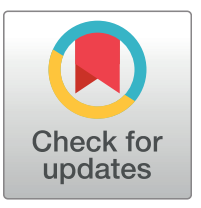

\section{openaccess}

Citation: Sun X, Lu L, Yang R, Li Y, Shan L, Wang $Y$ (2016) Increased Incidence of Thyroid Disease in Patients with Celiac Disease: A Systematic Review and Meta-Analysis. PLoS ONE 11(12): e0168708. doi:10.1371/journal.pone.0168708

Editor: Karol Sestak, Tulane University, UNITED STATES

Received: August 14, 2016

Accepted: November 22, 2016

Published: December 28, 2016

Copyright: $\odot 2016$ Sun et al. This is an open access article distributed under the terms of the Creative Commons Attribution License, which permits unrestricted use, distribution, and reproduction in any medium, provided the original author and source are credited.

Data Availability Statement: All relevant data are within the paper and its Supporting Information files.

Funding: The authors received no specific funding for this work.

Competing Interests: The authors have declared that no competing interests exist.

\section{Abstract}

The prevalence of thyroid disease is likely increased among individuals with celiac disease (CD). In addition, exposure to gluten-free treatment may be associated with a risk of thyroid disease, but this association remains controversial. A systematic review was performed to evaluate the association between thyroid disease and CD. The articles were obtained from the PubMed, Web of Science, Embase, and Chinese WanFang bibliographical databases for the period up to May 2016. The results were analysed in a meta-analysis with odds ratios (ORs) and corresponding 95\% confidence intervals (95\% Cls). There were 13 articles in this meta-analysis, including $15629 \mathrm{CD}$ cases and 79342 controls. Overall, the prevalence of thyroid disease in patients with $C D$ was significantly increased compared with that in the control groups (OR 3.08, 95\% Cl 2.67-3.56, $P<0.001$ ). Moreover, there was no significant difference in the OR between the gluten-treated and untreated groups (OR $1.08,95 \% \mathrm{Cl}$ $0.61-1.92, P=0.786)$. The results of our meta-analysis support the hypothesis that the prevalence of thyroid disease in patients with $C D$ is increased compared with that in controls, which suggests that CD patients should be screened for thyroid disease. The effect of gluten-free treatment on thyroid disease needs further investigation.

\section{Introduction}

Celiac disease $(\mathrm{CD})$ is an autoimmune disorder disease characterized by chronic inflammation and villous atrophy of the small intestine[1]. This disease is caused by the ingestion of glutencontaining foods and other environmental factors. As originally described in the 19th century, $\mathrm{CD}$ is characterized by steatorrhoea, vomiting, and cachexia in early childhood. The common clinical manifestations of CD include diarrhoea, emaciation, aphthous stomatitis, and malabsorption, and many patients exhibit only mild or no symptoms at all[2,3]. The working group of the European Society of Paediatric Gastroenterology and Nutrition recommend the use of serological tests as diagnostic criteria for $\mathrm{CD}$. However, the gold diagnostic standard for $\mathrm{CD}$ is still the histological changes in the small bowel mucosa. A life-long gluten-free diet is an effective and common method to treat $\mathrm{CD}[4]$. 
$\mathrm{CD}$ has a prevalence of approximately $1 \%$ among Western nations $[5,6]$. The associations of $\mathrm{CD}$ with ulcerative colitis, Crohn's disease, microscopic colitis, autoimmune liver diseases, and several other immune- and non-immune-based diseases in the digestive system are well recognized. However, many diseases outside the digestive system, such as autoimmune thyroid disease, Sjögren's syndrome, type 1 diabetes mellitus, and Addison's disease, are associated with $\mathrm{CD}$, in both its overt and silent forms[7]. For example, a meta-analysis based on 26605 patients with type 1 diabetes mellitus revealed a $6.0 \%$ prevalence of biopsy-confirmed $\mathrm{CD}$, which was increased compared with the prevalence among healthy controls[8].

Thyroid disease may be related to $\mathrm{CD}$ as well. The prevalence of thyroid disease among $\mathrm{CD}$ patients was $10.8 \%$ in Sweden[9]. Similarly, Hadithi et al. found that of 184 patients with CD, 39 (21\%) were positive for thyroid antibodies in a Dutch population[10]. Saleem et al. also investigated 106 patients with CD in Ireland between 1988 and 2004. The prevalence of thyroid disease was $7 \%$, which was higher than that of other diseases (rheumatoid disease $3 \%$, inflammatory bowel disease $4 \%$, and type 1 diabetes mellitus 2\%)[11]. Several studies failed to identify a significant relationship between CD and thyroid disease[12,13]. However, most of these studies were cross-sectional surveys and lacked controls. In addition, exposure to gluten-free treatment may be associated with a risk of thyroid disease[14,15], but this association remains uncertain.

The prevalence of thyroid disease is likely increased among individuals with CD. However, this association remains controversial. The purpose of this study was to evaluate the risk of thyroid disease in patients with $\mathrm{CD}$. A secondary objective was to study the effect of gluten-free treatment on thyroid disease.

\section{Methods}

A completed PRISMA checklist is presented in S1 File.

\section{Search}

A systematic literature search without language restriction was performed independently by two researchers (Y.W. and L.S.) using the PubMed, Web of Science, Embase, and Chinese WanFang bibliographical databases with the words "celiac disease" or "coeliac disease" in combination with the terms "thyroid disease", or "thyroiditis", or "thyroid antibody", or "hypothyroidism", or "hyperthyroidism" in the title or abstract. The literature was searched for the period up to May 2016. In addition, the reference lists of the retrieved articles were examined to identify additional eligible studies.

\section{Inclusion criteria}

Eligible studies included in this meta-analysis met all the following criteria: (1) all the CD patients were newly diagnosed or untreated with gluten; (2) a case-control or cohort design was used; (3) sufficient data on cases and controls were provided to enable calculation of the odds ratio (OR) with 95\% confidence interval (CI) and $P$-value. Reviews, case reports, and letters were excluded from this meta-analysis.

\section{Data extraction}

The following information was extracted from the included studies by two reviewers independently (L.L., Y.B.L.): first author, publication year, region, population, numbers of cases and controls, and details regarding thyroid disease in the cases and controls. Disagreements were 
resolved by discussion between two reviewers. If a consensus could not be reached, another reviewer settled the disagreement.

The patients in the studies were classified into four groups for further meta-analysis: (1) thyroid disease group, (2) euthyroidism autoimmune thyroid disease group, (3) hypothyroidism group, and (4) hyperthyroidism group. The thyroid disease group was defined as a group of patients with any abnormal thyroid function test, including elevated thyroid antibodies. The euthyroidism autoimmune thyroid disease group was defined as a group of patients with elevated thyroid antibodies in combination with normal thyroid function tests. The hypothyroidism group was defined as a group of patients with hypothyroid function in combination with or without elevated thyroid antibodies. The hypothyroidism group was defined as a group of patients with hyperthyroid function in combination with or without elevated thyroid antibodies.

\section{Risk of bias in included studies}

Two reviewers (L.L., Y.B.L.) independently, but without being blinded to the authors or journals, assessed the risk of bias in the included studies using the Newcastle-Ottawa Scale (NOS) [16]. The NOS is recommended by the Cochrane Handbook for Systematic Reviews of Interventions[17]. Each included study was judged according to 3 domains using the "star system": representativeness of study group selection (4 items), comparability of groups (two items), and ascertainment of either the exposure or outcome ( 3 items). NOS scores range from 0 to 9 stars. The studies assessed by both investigators were compared, and disagreement was resolved by consensus.

\section{Statistical analysis}

All data were analysed using STATA software, version 12.0 (Stata Corp LP, TX, USA). The risk of thyroid disease in patients with CD was evaluated by the OR with the corresponding 95\% $\mathrm{Cl}$. The significance of the $\mathrm{OR}$ was determined using the $\mathrm{Z}$ test. Heterogeneity among studies was measured with the $I^{2}$ index and $P$-value. $I^{2}$ index values of 25, 50 and 75\% were considered to indicate low, moderate and high levels of heterogeneity, respectively. A value of $0 \%$ indicated no observed heterogeneity. For low-level heterogeneity, we adopted a fixed-effects metaanalysis. If moderate or high heterogeneity existed, we adopted a random-effects meta-analysis instead of using a fixed-effects model. Next, we examined publication bias using Egger's test and Begg's test. For both tests, $P<0.1$ was considered statistically significant. Furthermore, funnel plots were used to analyse potential publication bias. For other analyses, $P<0.05$ was considered statistically significant.

\section{Results}

\section{Study inclusion and characteristics}

Fig 1 summarizes the selection process of studies evaluating the prevalence of thyroid disease in patients with $\mathrm{CD}$. A total of 13 relevant studies with a case-control or cohort design that investigated the relationship between thyroid disease and $\mathrm{CD}$ that met the study inclusion criteria were identified.

The initial search retrieved 2563 records from the PubMed, Web of Science, Embase, and Chinese WanFang bibliographical databases, and 478 articles remained after the exclusion of duplicates, reviews, and letters. After screening for eligibility based on the title and abstract, 43 articles were selected. Of these 43 selected articles, 13 articles were included after screening the full text[18-30]. The main reasons for inclusion in the full-text selection are shown in Fig 1. We chose these eligible studies for our meta-analysis, which included 15,629 CD cases and 


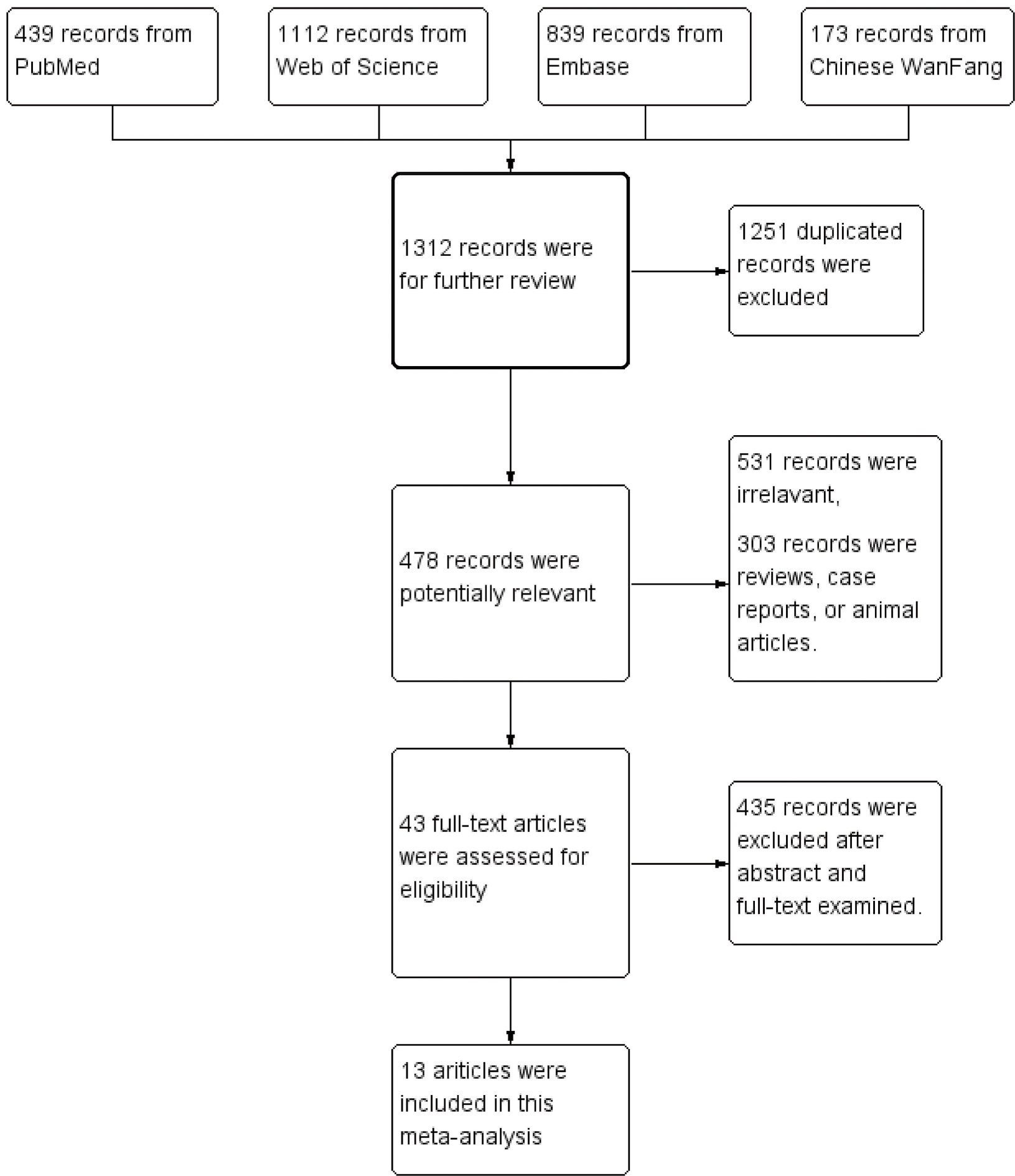

Fig 1. Flow charts showing the detailed procedure for the inclusion or exclusion of studies. Thirteen independent studies were included in this meta-analysis.

doi:10.1371/journal.pone.0168708.g001

79,342 controls. The characteristics of the selected studies are summarized in Table 1. Features of the studies comparing the incidence of thyroid disease in CD patients are presented in Table 2. 
Table 1. Study characteristics of the published studies included in the meta-analysis.

\begin{tabular}{|c|c|c|c|c|c|c|}
\hline & Region & Design & Population & Case (n) & Control (n) & Outcome \\
\hline Snook,1989 & Oxford & Case-control & Adult & 148 & $\begin{array}{l}\text { 300, patients with non-autoimmune } \\
\text { gastrointestinal disorders }\end{array}$ & $\begin{array}{l}\text { Hypothyrodism, } \\
\text { hyperthyrodism }\end{array}$ \\
\hline $\begin{array}{c}\text { Sategna- } \\
\text { Guidetti, } 1998\end{array}$ & Torino & $\begin{array}{l}\text { Case-control, } \\
\text { Prospective } \\
\text { cohort }\end{array}$ & Adult & $\begin{array}{l}53 \text { newly } \\
\text { diagnosed } 132 \text { on } \\
\text { a gluten-free diet }\end{array}$ & $\begin{array}{c}\text { 170, healthy volunteers, and patients with } \\
\text { peptic ulcer, non-ulcer dyspepsia, matched } \\
\text { for sex and age }\end{array}$ & $\begin{array}{c}\text { EATD, } \\
\text { hypothyrodism, } \\
\text { hyperthyrodism }\end{array}$ \\
\hline Velluzzi, 1998 & Carliari & Case-control & Adult & 47 & $\begin{array}{l}\text { 91, healthy subjects, matched for sex, age, } \\
\text { and ethnic origin }\end{array}$ & $\begin{array}{l}\text { Thyroid antibodies } \\
\text { positive }\end{array}$ \\
\hline $\begin{array}{l}\text { Kowalska, } \\
2000\end{array}$ & Poland & Case-control & Children & 34 & $\begin{array}{l}28, \text { children at similar age with dyspeptic } \\
\text { problems }\end{array}$ & $\begin{array}{l}\text { Thyroid antibodies } \\
\text { positive }\end{array}$ \\
\hline $\begin{array}{l}\text { Toscano, } \\
2000\end{array}$ & Roma & Case-control & Adolescent & $\begin{array}{l}25 \text { newly } \\
\text { diagnosed } 19 \text { on } \\
\text { a gluten-free diet }\end{array}$ & $\begin{array}{c}\text { 40, adolescent subjects aged between } 14 \\
\text { and } 19 \text { years }\end{array}$ & $\begin{array}{l}\text { Thyroid antibodies } \\
\text { positive }\end{array}$ \\
\hline Ventura, 2000 & Trieste, Pisa & Case-control & $\begin{array}{l}\text { Mean age } \\
10.1 \text { years }\end{array}$ & 90 & $\begin{array}{c}90 \text {, healthy university students (mean age } \\
20.5 \text { years) }\end{array}$ & $\begin{array}{l}\text { Thyroid antibodies } \\
\text { positive }\end{array}$ \\
\hline $\begin{array}{l}\text { Sategna- } \\
\text { Guidetti, } 2001\end{array}$ & $\begin{array}{l}\text { Carliari, Torino, } \\
\text { Bologna, } \\
\text { Perugia, Napoli }\end{array}$ & $\begin{array}{l}\text { Case-control, } \\
\text { Prospective } \\
\text { cohort }\end{array}$ & Adult & 241 & $\begin{array}{l}\text { 212, healthy volunteers, and patients with } \\
\text { chronic obstructive pulmonary, peptic } \\
\text { ulcer, non-ulcer dyspepsia, matched for } \\
\text { sex, age, and ethnic origin }\end{array}$ & $\begin{array}{l}\text { EATD, } \\
\text { hypothyrodism, } \\
\text { hyperthyrodism }\end{array}$ \\
\hline Ansaldi, 2003 & Torino & $\begin{array}{l}\text { Case-control, } \\
\text { Prospective } \\
\text { cohort }\end{array}$ & Children & 87 & $\begin{array}{c}\text { 199, subjects aged } 8 \text { months to } 17.3 \text { years, } \\
\text { were randomly selected from the areas of } \\
\text { patients, and had no immunologic and } \\
\text { gastrointestinal disorder. }\end{array}$ & $\begin{array}{l}\text { EATD, } \\
\text { hypothyrodism, } \\
\text { hyperthyrodism }\end{array}$ \\
\hline Guariso, 2007 & Padua & Case-control & Children & 267 & 220 , healthy children & $\begin{array}{c}\text { EATD, } \\
\text { hypothyrodism }\end{array}$ \\
\hline $\begin{array}{l}\text { Elfstrom, } \\
2008\end{array}$ & Sweden & Case-control & $\begin{array}{l}\text { Children, } \\
\text { Adult }\end{array}$ & 14021 & $\begin{array}{l}68068, \text { matched for age, sex, calendar } \\
\text { year, and area of residence }\end{array}$ & $\begin{array}{l}\text { EATD, } \\
\text { hypothyrodism, } \\
\text { hyperthyrodism }\end{array}$ \\
\hline Toumi, 2008 & Tunisia & $\begin{array}{l}\text { Case-control, } \\
\text { Prospective } \\
\text { cohort }\end{array}$ & Adult & $\begin{array}{l}56 \text { newly } \\
\text { diagnosed } 21 \text { on } \\
\text { a gluten-free diet }\end{array}$ & $\begin{array}{c}189, \text { normal blood donors (mean age } 26 \\
\text { years) }\end{array}$ & $\begin{array}{l}\text { Thyroid antibodies } \\
\text { positive }\end{array}$ \\
\hline Meloni, 2009 & Sardinia & $\begin{array}{l}\text { Case-control, } \\
\text { Prospective } \\
\text { cohort }\end{array}$ & Adult & 324 & $\begin{array}{l}\text { 8040, age-matched Sardinian background } \\
\text { population }\end{array}$ & $\begin{array}{l}\text { Thyroid antibodies } \\
\text { positive }\end{array}$ \\
\hline Pals, 2014 & Sweden & $\begin{array}{l}\text { Case-control, } \\
\text { Prospective } \\
\text { cohort }\end{array}$ & 12-year-old & $\begin{array}{c}242 \text { newly } \\
\text { diagnosed } 93 \text { on } \\
\text { a gluten-free diet }\end{array}$ & $\begin{array}{l}1695, \text { matched for sex, were randomly } \\
\text { selected from all cohort members free of } \\
\text { celiac disease at the time of diagnosis. }\end{array}$ & $\begin{array}{l}\text { Thyroid antibodies } \\
\text { positive }\end{array}$ \\
\hline
\end{tabular}

doi:10.1371/journal.pone.0168708.t001

The Newcastle-Ottawa Scale guidelines are widely used to evaluate case-control and cohort studies for quality. They contain Selection, Comparability, and Exposure categories. Overall, in accordance with the recommended criteria of the Newcastle-Ottawa Scale, the studies included in this meta-analysis were of acceptable quality; therefore, we did not exclude any article from the meta-analysis for quality reasons.

\section{Meta-analysis results}

The results of this meta-analysis indicated that the prevalence of thyroid disease among $\mathrm{CD}$ patients was significantly increased compared with that in the control groups (OR 3.08, 95\% CI 2.67-3.56, $P<0.001)$. The forest plots for the frequency of thyroid disease in patients with $\mathrm{CD}$ compared with controls are presented in Fig 2 . The risk of euthyroidism autoimmune thyroid disease in patients with $\mathrm{CD}$ was even higher; specifically, it was increased more than four-fold compared with that in patients without CD (OR 4.34, 95\% CI 2.88-6.56, $P<0.001$ ) (Fig 3). The prevalence of hypothyroidism among patients with $\mathrm{CD}$ was significantly increased compared with that in the control groups (OR 3.38, 95\% CI 2.73-4.20, $P<0.001$ ) (Fig 4). 
Table 2. Details of thyroid disease in patients with celiac disease and controls.

\begin{tabular}{|c|c|c|}
\hline & Thyroid disease in patients with celiac disease (n) & Thyroid disease in control ( $\mathrm{n}$ ) \\
\hline \multirow[t]{2}{*}{ Snook,1989 } & Hypothyrodism: 4 & Hypothyrodism: 2 \\
\hline & Hyperthyrodism: 2 & Hyperthyrodism: 2 \\
\hline \multirow[t]{3}{*}{ Sategna-Guidetti, 1998} & EATD: 6 & EATD: 8 \\
\hline & Hypothyrodism:3 & Hypothyrodism:1 \\
\hline & Hyperthyrodism: 1 & Hyperthyrodism: 10 \\
\hline Velluzzi, 1998 & Thyroid antibody positive: 14 & Thyroid antibody positive: 9 \\
\hline Kowalska, 2000 & Thyroid antibody positive: 14 & Thyroid antibody positive: 2 \\
\hline Toscano, 2000 & Thyroid antibody positive: 6 & Thyroid antibody positive: 3 \\
\hline Ventura,2000 & Thyroid antibody positive: 13 & Thyroid antibody positive: 4 \\
\hline \multirow[t]{3}{*}{ Sategna-Guidetti, 2001} & EATD: 39 & EATD: 8 \\
\hline & Hypothyrodism: 31 & Hypothyrodism: 9 \\
\hline & Hyperthyrodism: 3 & Hyperthyrodism: 7 \\
\hline \multirow[t]{3}{*}{ Ansaldi, 2003} & EATD: 15 & EATD: 12 \\
\hline & Hypothyrodism: 9 & Hypothyrodism: 7 \\
\hline & Hyperthyrodism: 0 & Hyperthyrodism: 0 \\
\hline \multirow[t]{2}{*}{ Guariso, 2007} & EATD: 13 & EATD: 1 \\
\hline & Hypothyrodism: 13 & Hypothyrodism: 0 \\
\hline \multirow[t]{3}{*}{ Elfstrom, 2008} & EATD: 17 & EATD: 24 \\
\hline & Hypothyrodism: 127 & Hypothyrodism: 191 \\
\hline & Hyperthyrodism: 48 & Hyperthyrodism: 100 \\
\hline Toumi, 2008 & Thyroid antibody positive: 1 & Thyroid antibody positive: 3 \\
\hline Meloni, 2009 & Thyroid antibody positive: 11 & Thyroid antibody positive: 235 \\
\hline Pals, 2014 & Thyroid antibody positive: 17 & Thyroid antibody positive: 8 \\
\hline
\end{tabular}

Euthyroidism autoimmune thyroid disease: EATD

doi:10.1371/journal.pone.0168708.t002

Unexpectedly, the prevalence of hyperthyroidism in patients with CD was not significantly increased compared with that in the control groups (OR 1.28, 95\% CI 0.37-4.46, $P=0.693$ ) (Fig 5). There was no heterogeneity in our meta-analysis of the association of euthyroidism autoimmune thyroid disease and hypothyroidism with $\mathrm{CD}\left(I^{2}=0, P=0.475,0.682\right.$, respectively). Moreover, there was no significant difference in the OR between the gluten-treated and untreated groups (OR 1.08, 95\% CI 0.61-1.92, P = 0.786) (Fig 6).

\section{Publication bias}

We carefully and comprehensively searched the articles in the database. To determine whether potential publication bias existed in the reviewed literature, Begg's test and Egger's test were conducted. Begg's and Egger's tests are used to statistically determine the symmetries of the funnel plots. The results of Begg's test $(P=0.602)$ and Egger's test $(P=0.484)$ did not suggest the existence of publication bias. The funnel plot is shown in Fig 7 .

\section{Discussion}

Some studies have evaluated the risk of thyroid disease in patients with $\mathrm{CD}$, but the results of these studies have not been consistent. Due to the relatively small sample size of these studies, it is difficult to determine the association between $\mathrm{CD}$ and thyroid disease. The present systematic review summarized and quantitatively evaluated the evidence for an increased risk of thyroid disease in patients with CD. Thirteen independent, relevant studies with case-control 
Study

ID

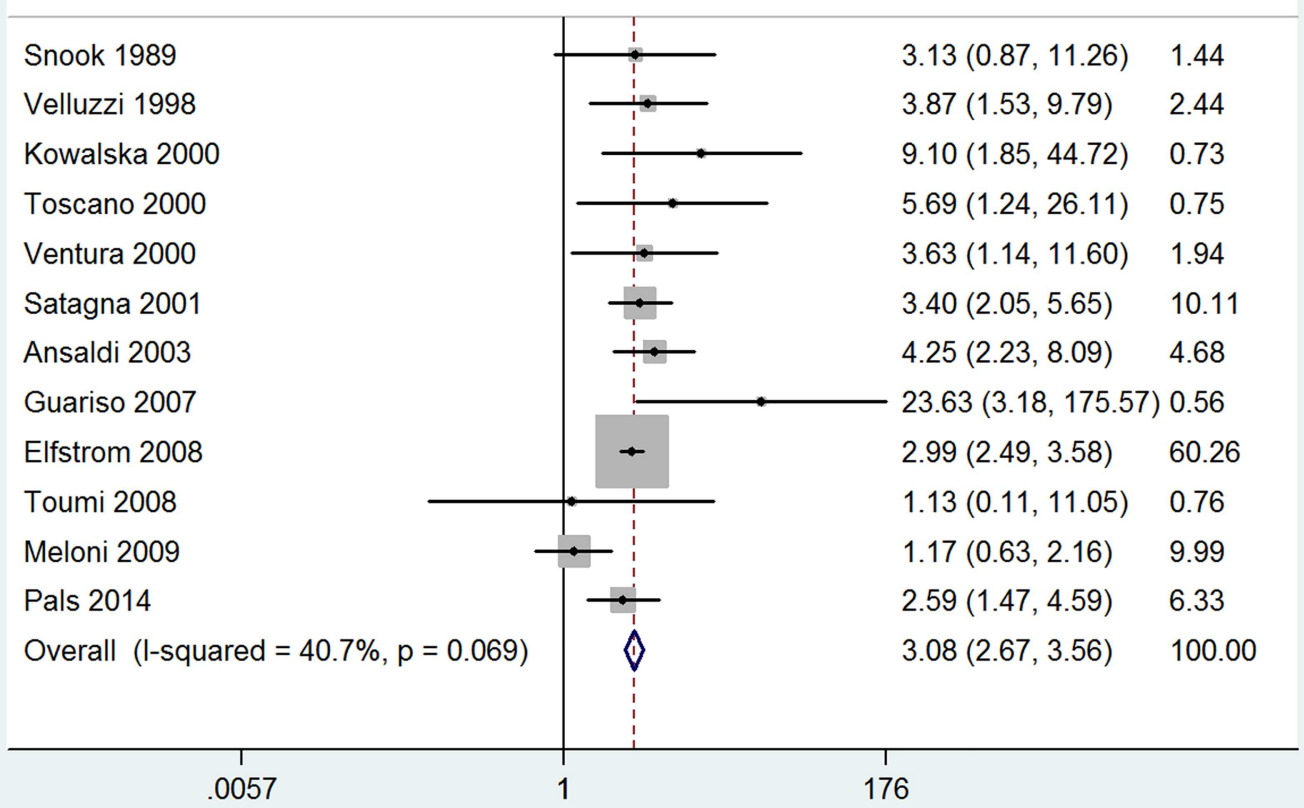

Fig 2. Forest plots for the frequency of thyroid disease in patients with celiac disease compared to that in controls. The diamond represents the pooled OR and $95 \% \mathrm{Cl}$.

doi:10.1371/journal.pone.0168708.g002

Study

ID

\begin{tabular}{|c|c|c|}
\hline Satagna 2001 & $4.92(2.25,10.80)$ & 32.60 \\
\hline Ansaldi 2003 & $3.25(1.45,7.27)$ & 27.61 \\
\hline Guariso 2007 & $23.39(1.38,395.78)$ & 2.38 \\
\hline Elfstrom 2008 & $3.44(1.85,6.41)$ & 37.42 \\
\hline Overall $(I-$ squared $=0.0 \%, p=0.475$ ) & $4.35(2.88,6.56)$ & 100.00 \\
\hline .00253 & 396 & \\
\hline
\end{tabular}

Fig 3. Forest plots for the frequency of euthyroidism autoimmune thyroid disease in patients with celiac disease compared to that in controls. The diamond represents the pooled OR and $95 \% \mathrm{Cl}$.

doi:10.1371/journal.pone.0168708.g003 
Study

ID
$\%$

OR $(95 \% \mathrm{Cl})$

Weight

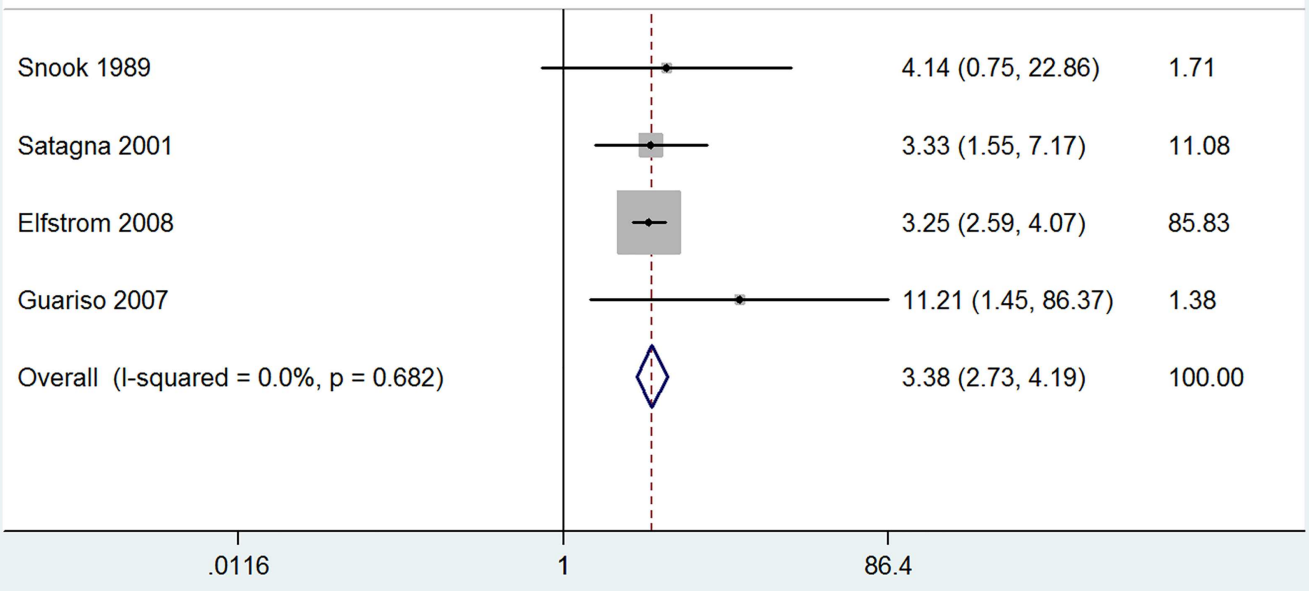

Fig 4. Forest plots for the frequency of hypothyroidism in patients with celiac disease compared to that in controls. The diamond represents the pooled OR and $95 \% \mathrm{Cl}$.

doi:10.1371/journal.pone.0168708.g004

Study

ID

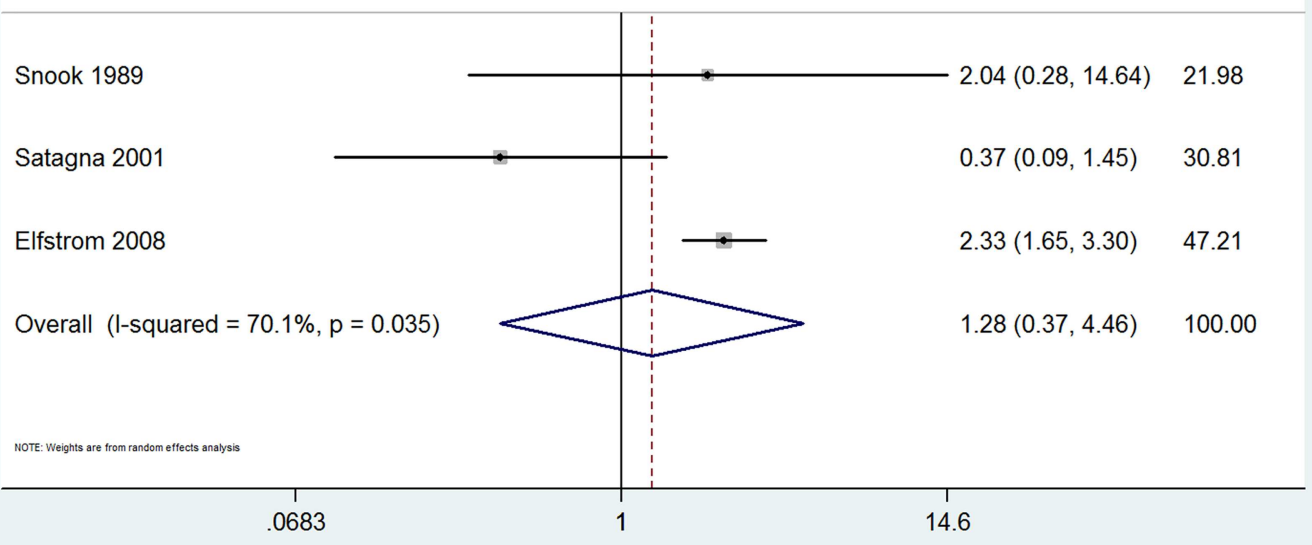

Fig 5. Forest plots for the frequency of hyperthyroidism in patients with celiac disease compared to that in controls. The diamond represents the pooled OR and $95 \% \mathrm{Cl}$.

doi:10.1371/journal.pone.0168708.g005 


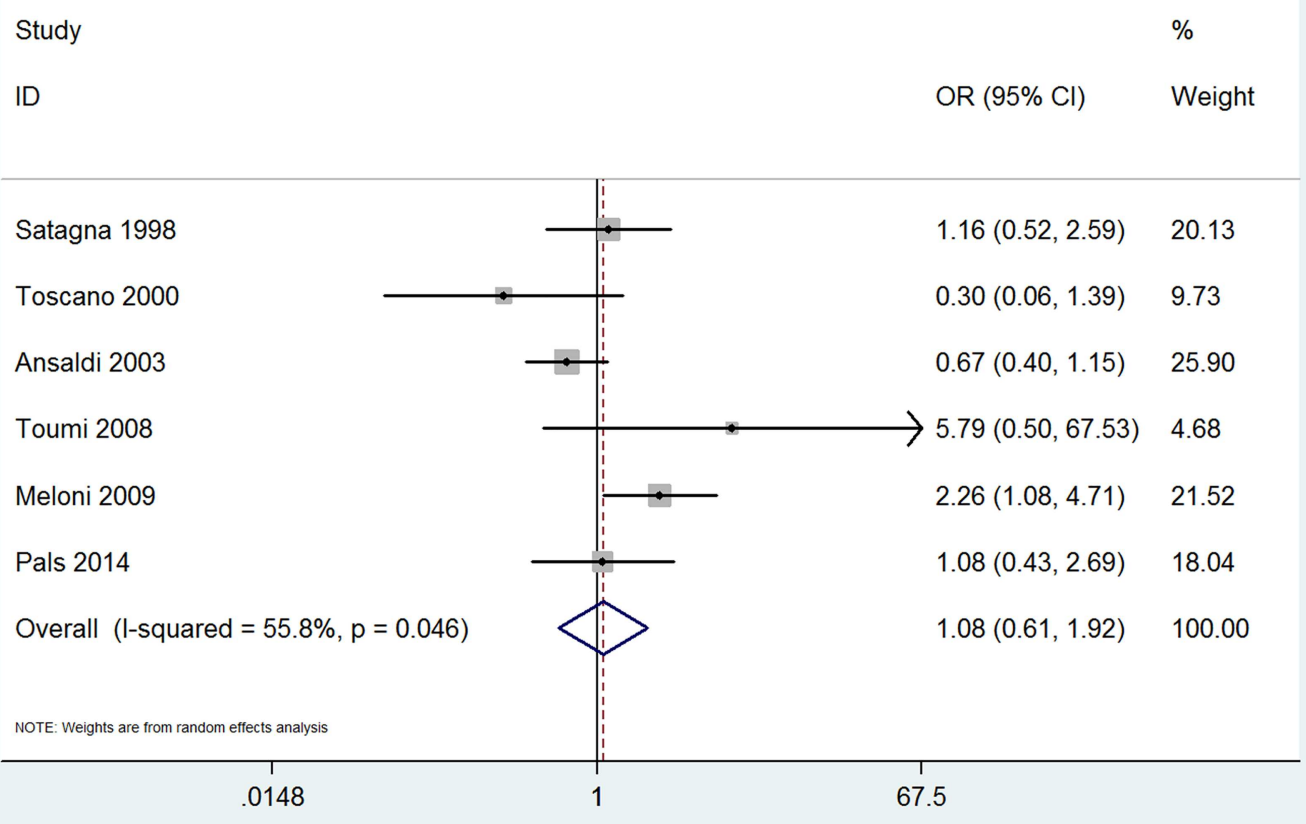

Fig 6. Forest plots for the frequency of thyroid disease in gluten-free-treated patients with celiac disease compared to that in untreated patients. The diamond represents the pooled OR and $95 \% \mathrm{Cl}$.

doi:10.1371/journal.pone.0168708.g006

and cohort designs were included in our meta-analysis. The results of this meta-analysis showed that the prevalence of thyroid disease in $\mathrm{CD}$ patients was significantly increased compared to that in the control groups (OR 3.08, 95\% CI 2.67-3.56, $P<0.001$ ). The risk of euthyroidism autoimmune thyroid disease among patients with $\mathrm{CD}$ was increased more than four-fold compared with that in patients without $\mathrm{CD}$. The prevalence of hypothyroidism in patients with $\mathrm{CD}$ was significantly increased compared with that in the control groups. However, there was no significant association between hyperthyroidism and CD. Overall, the heterogeneity in our meta-analysis was low, particularly in that of euthyroidism autoimmune thyroid disease and hypothyroidism $\left(I^{2}=0\right)$, indicating that the studies included in our meta-analysis were statistically reliable.

Mechanisms that underlie the coexistence of $\mathrm{CD}$ and thyroid disease are complex and not yet fully understood. The association can, at least partly, be explained by shared genetic factors. Human leukocyte antigen (HLA) DQ2 and DQ8 haplotypes are over-expressed in CD, and the inheritance of these haplotypes and the associated immunological phenotype may explain this association. HLA-DQ2 and DQ8 also exhibit a weak association with Hashimoto's thyroiditis; however, the relationship between the HLA-DQ2 haplotype and Graves' disease is unclear[3137]. Most hypothyroidism and hyperthyroidism cases are Hashimoto's disease and Graves' disease, respectively. In our meta-analysis, there was a significant association between hypothyroidism and CD, but no significant association between hyperthyroidism and CD was observed. Our results are consistent with an earlier mechanistic study.

In addition, the gene encoding cytotoxic T-lymphocyte-associated antigen-4 (CTLA-4) is associated with CD and autoimmune thyroid disease. CTLA-4 is a candidate gene outside the HLA region that is associated with thyroid autoimmunity and exhibits a strong association with $\mathrm{CD}[38-40]$. Moreover, Valentino et al. investigated the genotypes of 14 patients with Hashimoto's thyroiditis compatible with CD. Three patients had DQ heterodimers $\mathrm{A1}{ }^{*} 0501$, 
Funnel plot with pseudo $95 \%$ confidence limits

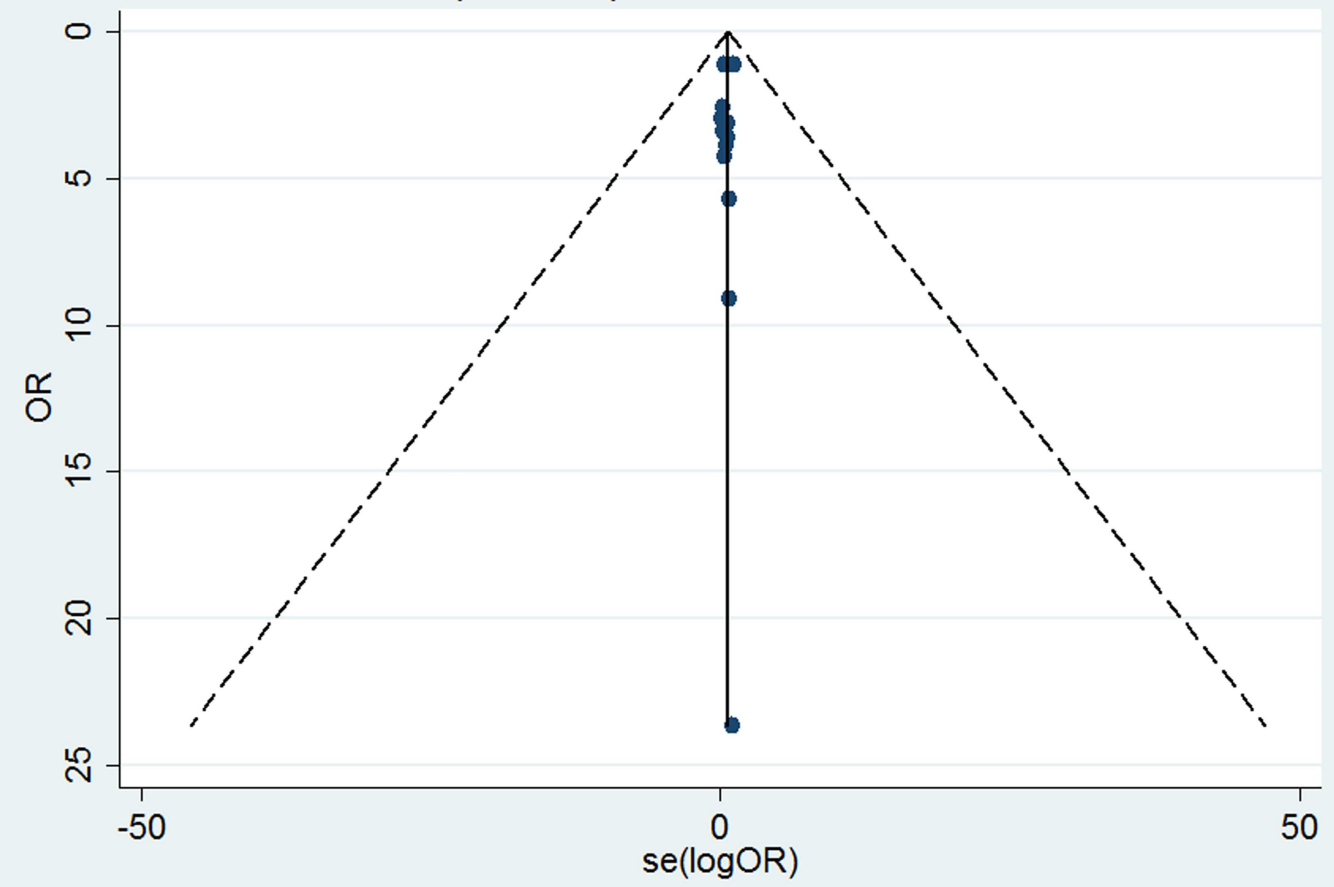

Fig 7. Funnel plot for testing the publication bias of the association between celiac disease and the risk of thyroid disease. Each point represents an individual study on the indicated association. The vertical line indicates the effect size.

doi:10.1371/journal.pone.0168708.g007

$\mathrm{B} 1^{*} 0201$, four had $\mathrm{DRB} 1^{*} 04$, and one had $\mathrm{A} 1^{*} 0101, \mathrm{~B} 1^{*} 0501$. An increased density of $\gamma \delta+$ T-cell receptor-bearing intra-epithelial lymphocytes was observed in 6 patients. Mucosal T cell activation (presence of interleukin 2 (IL2) receptors (CD25) on lamina propria T cells and/or expression of HLA-DR molecules on crypt epithelial cells, both typical of CD) was noted in those 6 patients. Additionally, in 4 of 6 patients, HLA genotypes associated with CD (three with DRB1*04, DQB1*03 and one with DQA1*0501, DQB1*02) were described[41].

There has been significant debate regarding whether a gluten-free treatment in $\mathrm{CD}$ protects against thyroid disease or alters the natural history of the disease. In addition to the studies in this meta-analysis, Cooper et al. concluded that gluten-free treatment did not delay the development of thyroid disease and had little ameliorating effect on the disease course, aside from an occasional improvement in atopy[42]. In addition, Viljamaa et al. and Mainardi et al. both reported no association between duration of gluten exposure in adult $\mathrm{CD}$ patients and thyroid disease risk $[13,43]$. All these related studies lacked a strict design, and randomized controlled trials investigating the effect of gluten on thyroid disease in CD patients were absent. Due to the limited data on the effect of gluten on thyroid disease, only 6 articles were included in our meta-analysis. In our study, we found no significant difference in thyroid disease between the gluten-treated and untreated groups.

\section{Limitations}

The main purpose of this meta-analysis was to investigate the risk of thyroid disease in patients with CD compared with controls using statistical methods. However, there were some 
limitations in our meta-analysis. First, CD is more common in Western countries than Asian and African countries, and all the studies in our meta-analysis are from Western countries. The relationship between thyroid disease and CD in other ethnic groups and regions was not investigated in this meta-analysis. Second, due to the lack of randomized controlled trials investigating the effect of gluten on thyroid disease in CD patients, the studies included in this meta-analysis were only case-control and retrospective cohort studies. Evidence of an effect of gluten on thyroid disease in this meta-analysis was not strong, and more studies are required. Furthermore, because the studies included were performed at highly diverse time points over approximately 30 years, the variability of the assays used in each study may have influenced the results. Therefore, the results of this meta-analysis should be interpreted with caution.

\section{Conclusions}

In conclusion, the results of our meta-analysis support the hypothesis that the prevalence of thyroid disease, especially euthyroidism autoimmune thyroid disease and hypothyroidism, in patients with $\mathrm{CD}$ is increased compared with that in controls, which suggests that CD patients should be screened for thyroid disease. Moreover, the effect of gluten-free treatment on thyroid disease needs further investigation.

\section{Supporting Information}

S1 File. PRISMA Checklist.

(DOC)

S2 File. Search strategy of data in PubMed.

(DOC)

\section{Acknowledgments}

We thank American Journal Experts (AJE) for English language editing. This manuscript was edited for English language by American Journal Experts (AJE).

\section{Author Contributions}

\section{Conceptualization: XS.}

Data curation: LS YW.

Formal analysis: LL YL.

Investigation: LL YL.

Methodology: LS.

Project administration: XS.

Resources: XS.

Software: YW.

Supervision: LL YL.

Validation: LL.

Visualization: RY.

Writing - original draft: XS RY. 
Writing - review \& editing: LL.

\section{References}

1. Green PHR, Cellier C. Celiac disease. N Engl J Med. 2007; 357: 1731-1743. doi: 10.1056/ NEJMra071600 PMID: 17960014

2. Fasano A. Clinical presentation of celiac disease in the pediatric population. Gastroenterology. 2005; 128: S68-S73. PMID: 15825129

3. Barker JM, Liu E. Celiac disease: pathophysiology, clinical manifestations, and associated autoimmune conditions. Adv Pediatr. 2008; 55: 349-365. doi: 10.1016/j.yapd.2008.07.001 PMID: 19048738

4. Lionetti $\mathrm{E}$, Catassi $\mathrm{C}$. New clues in celiac disease epidemiology, pathogenesis, clinical manifestations, and treatment. Int Rev Immunol. 2011; 30: 219-231. doi: 10.3109/08830185.2011.602443 PMID: 21787227

5. Mustalahti K, Catassi C, Reunanen A, Fabiani E, Heier M, McMillan S, et al. The prevalence of celiac disease in Europe: results of a centralized, international mass screening project. Ann Med. 2010; 42: 587-595. doi: 10.3109/07853890.2010.505931 PMID: 21070098

6. Dubé C, Rostom A, Sy R, Cranney A, Saloojee N, Garritty C, et al. The prevalence of celiac disease in average-risk and at-risk Western European populations: a systematic review. Gastroenterology. 2005; 128: S57-S67. PMID: 15825128

7. Collin $\mathrm{P}$, Kaukinen K, Välimäki M, Salmi J. Endocrinological disorders and celiac disease. Endocr Rev. 2002; 23: 464-483. doi: 10.1210/er.2001-0035 PMID: 12202461

8. Elfström P, Sundström J, Ludvigsson JF. Systematic review with meta-analysis: association setween coeliac disease and type 1 diabetes. Aliment Pharmacol Ther. 2014; 40: 1123-1132. doi: 10.1111/apt. 12973 PMID: 25270960

9. Midhagen G, Järnerot G, Kraaz W. Adult coeliac disease within a defined geographic area in Sweden. A study of prevalence and associated diseases. Scand J Gastroenterol. 1988; 23: 1000-1004. PMID: 3201123

10. Horwitz A, Skaaby T, Kårhus LL, Schwarz P, Jørgensen T, Rumessen JJ, et al. Screening for celiac disease in Danish adults. Scand J Gastroenterol. 2015; 50: 824-831. doi: 10.3109/00365521.2015. 1010571 PMID: 25687734

11. Saleem A, Connor HJ, Regan PO. Adult coeliac disease in Ireland: a case series. Ir J Med Sci. 2012; 181: 225-229. doi: 10.1007/s11845-011-0788-z PMID: 22203320

12. Collin $P$, Reunala T, Pukkala E, Laippala P, Keyriläinen O, Pasternack A. Coeliac disease-associated disorders and survival. Gut. 1994; 35: 1215-1218. PMID: 7959226

13. Viljamaa M, Kaukinen $\mathrm{K}$, Huhtala $\mathrm{H}$, Kyrönpalo $\mathrm{S}$, Rasmussen $\mathrm{M}$, Collin P. Coeliac disease, autoimmune diseases and gluten exposure. Scand J Gastroenterol. 2005; 40: 437-443. PMID: 16028438

14. Ventura A, Magazzù G, Greco L. Duration of exposure to gluten and risk for autoimmune disorders in patients with celiac disease. SIGEP Study Group for Autoimmune Disorders in Celiac Disease. Gastroenterology. 1999; 117: 297-303. PMID: 10419909

15. Sategna-Guidetti C, Solerio E, Scaglione N, Aimo G, Mengozzi G. Duration of gluten exposure in adult coeliac disease does not correlate with the risk for autoimmune disorders. Gut. 2001; 49: 502-505. doi: 10.1136/gut.49.4.502 PMID: 11559646

16. Wells GA, Shea B, O'Connell D, Peterson J, Welch V, Losos M, et al. The Newcastle-Ottawa Scale (NOS) for assessing the quality of nonrandomised studies in meta-analyses. Available: http://www.ohri. ca/programs/clinical_epidemiology/oxford.asp. Accessed 2014 Aug 5.

17. Higgins JPT, Green S. Cochrane Handbook for Systematic Reviews of Interventions Version 5.1.0. Available: http://www.cochrane-handbook.org. Accessed 2014 Aug

18. Snook JA, de Silva HJ, Jewell DP. The association of autoimmune disorders with inflammatory bowel disease. Q J Med. 1989; 72: 835-840. PMID: 2616728

19. Sategna-Guidetti C, Bruno M, Mazza E, Carlino A, Predebon S, Tagliabue M, Brossa C. Autoimmune thyroid diseases and coeliac disease. Eur J Gastroenterol Hepatol. 1998; 10: 927-931. PMID: 9872614

20. Velluzzi F, Caradonna A, Boy MF, Pinna MA, Cabula R, Lai MA, et al. Thyroid and celiac disease: clinical, serological, and echographic study. Am J Gastroenterol. 1998; 93: 976-979. doi: 10.1111/j.15720241.1998.291_u.x PMID: 9647032

21. Kowalska E, Wasowska-Królikowska K, Toporowska-Kowalska E. Estimation of antithyroid antibodies occurrence in children with coeliac disease. Med Sci Monit. 2000; 6: 719-721. PMID: 11208398 
22. Ventura A, Neri E, Ughi C, Leopaldi A, Città A, Not T. Gluten-dependent diabetes-related and thyroidrelated autoantibodies in patients with celiac disease. J Pediatr. 2000; 137: 263-265. doi: 10.1067/ mpd.2000.107160 PMID: 10931424

23. Toscano V, Conti FG, Anastasi E, Mariani P, Tiberti C, Poggi M, et al. Importance of gluten in the induction of endocrine autoantibodies and organ dysfunction in adolescent celiac patients. Am J Gastroenterol. 2000; 95: 1742-1748. doi: 10.1111/j.1572-0241.2000.02187.x PMID: 10925978

24. Sategna-Guidetti C, Volta U, Ciacci C, Usai P, Carlino A, De Franceschi L, et al. Prevalence of thyroid disorders in untreated adult celiac disease patients and effect of gluten withdrawal: an Italian multicenter study. Am J Gastroenterol. 2001; 96: 751-757. doi: 10.1111/j.1572-0241.2001.03617.x PMID: 11280546

25. Ansaldi N, Palmas T, Corrias A, Barbato M, D'Altiglia MR, Campanozzi A, et al. Autoimmune thyroid disease and celiac disease in children. J Pediatr Gastroenterol Nutr. 2003; 37: 63-66. PMID: 12827007

26. Guariso G, Conte S, Presotto F, Basso D, Brotto F, Visonà Dalla Pozza L, et al. Clinical, subclinical and potential autoimmune diseases in an Italian population of children with coeliac disease. Aliment Pharmacol Ther. 2007; 26: 1409-1417. doi: 10.1111/j.1365-2036.2007.03526.x PMID: 17892522

27. Elfström P, Montgomery SM, Kämpe O, Ekbom A, Ludvigsson JF. Risk of thyroid disease in individuals with celiac disease. J Clin Endocrinol Metab. 2008; 93: 3915-3921. doi: 10.1210/jc.2008-0798 PMID: 18611971

28. Toumi D, Mankai A, Belhadj R, Ghedira-Besbes L. Jeddi M, Ghedira I. Thyroid-related autoantibodies in Tunisian patients with coeliac disease. Clin Chem Lab Med. 2008; 46: 350-353. doi: 10.1515/CCLM. 2008.075 PMID: 18303988

29. Meloni A, Mandas $C$, Jores RD, Congia M. Prevalence of autoimmune thyroiditis in children with celiac disease and effect of gluten withdrawal. J Pediatr. 2009; 155: 51-55. doi: 10.1016/j.jpeds.2009.01.013 PMID: 19324373

30. van der Pals M, Ivarsson A, Norström F, Högberg L, Svensson J, Carlsson A, et al. Prevalence of thyroid autoimmunity in children with celiac disease compared to healthy 12-year olds. Autoimmune Dis. 2014; 2014: 417356. doi: 10.1155/2014/417356 PMID: 24592326

31. Lorini R, Larizza D, Scotta MS, Severi F. HLA in Graves' disease coexistent with coeliac disease. Eur J Pediatr. 1986; 145: 241-285. PMID: 3769988

32. Dalton TA, Bennett JC. Autoimmune disease and the major histocompatibility complex: therapeutic implications. Am J Med. 1992; 92: 183-188. PMID: 1543203

33. Kaukinen K, Collin P, Mykkänen AH, Partanen J, Mäki M, Salmi J. Celiac disease and autoimmune endocrinologic disorders. Dig Dis Sci. 1999; 44, 1428-1433. PMID: 10489930

34. Badenhoop K, Dieterich W, Segni M, Hofmann S, Hüfner M, Usadel KH, et al. HLA DQ2 and/or DQ8 is associated with celiac disease-specific autoantibodies to tissue transglutaminase in families with thyroid autoimmunity. Am J Gastroenterol. 2001; 96: 1648-1649. doi: 10.1111/j.1572-0241.2001.03821.x PMID: 11374722

35. Green JR, Chiew MK, Low HC, Woodrow JC. The association between HLA antigens and the presence of certain diseases. Stat Med. 1983; 2: 79-85. PMID: 6648122

36. Weetman AP, McGregor AM. Autoimmune thyroid disease: further developments in our understanding. Endocr Rev. 1994; 15: 788-830. doi: 10.1210/edrv-15-6-788 PMID: 7705281

37. Yanagawa T, Mangklabruks A, Chang YB, Okamoto Y, Fisfalen ME, Curran PG, et al. Human histocompatibility leukocyte antigen-DQA $1{ }^{*} 0501$ allele associated with genetic susceptibility to Graves' disease in a Caucasian population. J Clin Endocrinol Metab. 1993; 76: 1569-1574. doi: 10.1210/jcem.76. 6.8501164 PMID: 8501164

38. Hunt KA, McGovern Dermot PB, Kumar PJ, Ghosh S, Travis Simon PL, Walters Julian RF, et al. A common CTLA4 haplotype associated with coeliac disease. Eur J Hum Genet. 2005; 13: 440-444. doi: 10. 1038/sj.ejhg.5201357 PMID: 15657618

39. Chistiakov DA, Turakulov RI. CTLA-4 and its role in autoimmune thyroid disease. J. Mol Endocrinol. 2003; 31: 21-36. PMID: 12914522

40. King AL, Moodie SJ, Fraser JS, Curtis D, Reid E, Dearlove AM, et al. Coeliac disease: investigation of proposed causal variants in the CTLA4 gene region. Eur J Immunogenet. 2003; 30: 427-432. PMID: 14675397

41. Valentino R, Savastano S, Maglio M, Paparo F, Ferrara F, Dorato M, et al. Markers of potential coeliac disease in patients with Hashimoto's thyroiditis. Eur J Endocrinol. 2002; 146: 479-483. PMID: 11916614

42. Cooper BT, Holmes GK, Cooke WT. Coeliac disease and immunological disorders. Br Med J. 1978; 1 : 537-539. PMID: 630212

43. Mainardi E, Montanelli A, Dotti M, Nano R, Moscato G. Thyroid-related autoantibodies and celiac disease: a role for a gluten-free diet? J Clin Gastroenterol. 2002; 35: 245-248. PMID: 12192201 